\title{
Impaired Hippocampal Glutamate and Glutamine Metabolism in the db/db Mouse Model of Type 2 Diabetes Mellitus
}

\author{
Jens Velde Andersen, Jakob Dahl Nissen, Sofie Kjellerup Christensen, \\ Kia Hjulmand Markussen, and Helle Sønderby Waagepetersen
}

\author{
Department of Drug Design and Pharmacology, Faculty of Health and Medical Sciences, University of Copenhagen, \\ Copenhagen, Denmark \\ Correspondence should be addressed to Helle Sønderby Waagepetersen; helle.waagepetersen@sund.ku.dk
}

Received 27 February 2017; Accepted 10 April 2017; Published 14 June 2017

Academic Editor: João M. N. Duarte

Copyright (C) 2017 Jens Velde Andersen et al. This is an open access article distributed under the Creative Commons Attribution License, which permits unrestricted use, distribution, and reproduction in any medium, provided the original work is properly cited.

\begin{abstract}
Type 2 diabetes mellitus (T2DM) is a risk factor for the development of Alzheimer's disease, and changes in brain energy metabolism have been suggested as a causative mechanism. The aim of this study was to investigate the cerebral metabolism of the important amino acids glutamate and glutamine in the $\mathrm{db} / \mathrm{db}$ mouse model of T2DM. Glutamate and glutamine are both substrates for mitochondrial oxidation, and oxygen consumption was assessed in isolated brain mitochondria by Seahorse XFe96 analysis. In addition, acutely isolated cerebral cortical and hippocampal slices were incubated with $\left[\mathrm{U}_{-}{ }^{13} \mathrm{C}\right] \mathrm{glutamate}$ and $\left[\mathrm{U}_{-}{ }^{13} \mathrm{C}\right]$ glutamine, and tissue extracts were analyzed by gas chromatography-mass spectrometry. The oxygen consumption rate using glutamate and glutamine as substrates was not different in isolated cerebral mitochondria of $\mathrm{db} / \mathrm{db}$ mice compared to controls. Hippocampal slices of $\mathrm{db} / \mathrm{db}$ mice exhibited significantly reduced ${ }^{13} \mathrm{C}$ labeling in glutamate, glutamine, GABA, citrate, and aspartate from metabolism of $\left[\mathrm{U}_{-}{ }^{13} \mathrm{C}\right]$ glutamate. Additionally, reduced ${ }^{13} \mathrm{C}$ labeling were observed in GABA, citrate, and aspartate from $\left[\mathrm{U}_{-}{ }^{13} \mathrm{C}\right]$ glutamine metabolism in hippocampal slices of $\mathrm{db} / \mathrm{db}$ mice when compared to controls. None of these changes were observed in cerebral cortical slices. The results suggest specific hippocampal impairments in glutamate and glutamine metabolism, without affecting mitochondrial oxidation of these substrates, in the $\mathrm{db} / \mathrm{db}$ mouse.
\end{abstract}

\section{Introduction}

Type 2 diabetes mellitus (T2DM) is a multifaceted metabolic disease characterized by an augmented level of blood glucose caused by insulin resistance. T2DM has reached pandemic proportions as over 400 million people are affected by diabetes [1]. T2DM is a major risk factor for the development of Alzheimer's disease (AD), and the hippocampus seems to be particularly vulnerable in T2DM [2-4]. Insulin resistance has been associated with reductions in cerebral glucose utilization, a clinical hallmark of $\mathrm{AD}[5,6]$. This observation suggests that altered brain energy metabolism might be an accelerating factor in the development of $\mathrm{AD}$ in T2DM.

Glutamate is the main excitatory neurotransmitter in the mammalian brain. Timely clearance and handling of glutamate is essential for normal cerebral function [7]. The majority of released neurotransmitter glutamate is removed from the synapse by adjacent astrocytes. In the astrocyte, glutamate can be converted into glutamine by the astrocyte-specific enzyme glutamine synthetase (GS). Glutamine can subsequently be transported to the neurons and converted back into glutamate by the enzyme phosphate-activated glutaminase (PAG), mainly expressed in the neurons. The exchange of glutamate and glutamine between neurons and astrocytes is termed the glutamate/glutamine cycle $[7,8]$. Glutamate and glutamine are also linked to cellular energy homeostasis. Glutamate can be converted into $\alpha$-ketoglutarate by activity of glutamate dehydrogenase (GDH) or aspartate aminotransferase (AAT) and thus be oxidized in the tricarboxylic acid (TCA) cycle [9-11]. Glutamine must be converted into glutamate prior to oxidation. Both neurons and astrocytes are able to metabolize glutamate and 
glutamine [12-14]. It has recently been shown that oxidation of glutamate through GDH is important for cerebral energy homeostasis [15].

Previously, we have shown that the common T2DM mouse model, the $\mathrm{db} / \mathrm{db}$ mouse, exhibits reduced glucose utilization in both the cerebral cortex and hippocampus [16]. In addition to this, isolated cerebral mitochondria consumed more oxygen when given pyruvate and malate as substrates. Here, we sought to investigate if cerebral glutamate and glutamine metabolism is altered in the $\mathrm{db} / \mathrm{db}$ mouse. To assess this, oxygen consumption, that is, respiration, of isolated whole-brain mitochondria was determined by Seahorse XFe96 analysis, providing glutamate and glutamine as primary substrates. Furthermore, acutely isolated cerebral cortical and hippocampal slices of control and $\mathrm{db} / \mathrm{db}$ mice were incubated in media containing ${ }^{13} \mathrm{C}$-labeled glutamate or glutamine and tissue extracts were subsequently analyzed by gas chromatography-mass spectrometry (GC-MS) to determine ${ }^{13} \mathrm{C}$ enrichment and map the metabolism. Finally, the expression of enzymes important for glutamate/glutamine homeostasis was assessed by Western blotting.

\section{Methods}

2.1. Materials. The stable isotopes $\left[\mathrm{U}_{-}{ }^{13} \mathrm{C}\right]$ glutamate and $\left[\mathrm{U}_{-}{ }^{13} \mathrm{C}\right]$ glutamine (both $\mathrm{L}$ isoform and $99 \%$ purity) were purchased from Cambridge Isotope Laboratories (Tewksbury, MA, USA). The following antibodies were purchased from Abcam (Cambridge, United Kingdom): glutamate dehydrogenase (GDH, rabbit: ab34786), aspartate aminotransferase (AAT, mouse: ab93928), glutamate decarboxylase 65 and 67 (GAD65 and 67, both mouse: ab26113 and ab26116), phosphate-activated glutaminase (PAG, rabbit: ab93434), and glutamine synthetase (GS, rabbit: ab73593). All other chemicals used were of the purest grade available from regular commercial sources.

2.2. Animals. Diabetic and obese homozygote $\mathrm{db} / \mathrm{db}$ and control mice (blood glucose: $25.6 \pm 1.3 \mathrm{mmol} / \mathrm{L}$ versus 11.1 $\pm 0.4 \mathrm{mmol} / \mathrm{L}$, body weight: $51.6 \pm 0.8 \mathrm{~g}$ versus $28.2 \pm 0.9 \mathrm{~g}$ ) were obtained through mating of heterozygote $(\mathrm{db} /-)$ mice at the Department of Drug Design and Pharmacology, University of Copenhagen. The breeding pairs were obtained from Jackson Laboratories (Bar Harbor, ME, USA) on a C57BL/6J background. All animals were kept in a humidity-controlled facility with $12 / 12 \mathrm{~h}$ light/dark cycle and free access to water and chow. Animals were used at 15-16 weeks of age and grouped according to obese phenotype, meaning both lean wild-type and heterozygote offspring were used as controls as they cannot be phenotypically distinguished $[17,18]$. Both male and female mice were included in this study. Blood glucose levels were assessed using a BAYER Breeze 2 instrument. The experiments were approved by the Danish National Ethics Committee and were performed in agreement with the European Convention (ETS 123 of 1986).

2.3. Mitochondrial Isolation and Seahorse XFe96 Analysis. Whole-brain mitochondria of control and $\mathrm{db} / \mathrm{db}$ mice were isolated in tandem as described previously [16]. Briefly, animals were euthanized by cervical dislocation, the brain quickly removed and placed in cold isolation buffer containing the following in mM: mannitol 210, sucrose 70, HEPES 5, EGTA 1 and 0.5\% BSA (fatty acid free), $\mathrm{pH} 7.2$, and homogenized using a Teflon douncer (750 revolutions/min, 7-8 strokes). The mitochondria in the homogenate were isolated using a 21\% Percoll gradient, and protein amounts were determined by the Bradford method. The oxygen consumption rate (OCR) of the isolated cerebral mitochondria was assessed at $37^{\circ} \mathrm{C}$ using a Seahorse XFe96 analyzer (Seahorse Biosciences, MA, USA). The isolated mitochondria were suspended in assay buffer containing the following in $\mathrm{mM}$ : mannitol 220, sucrose 70, $\mathrm{KH}_{2} \mathrm{PO}_{4} 10, \mathrm{MgCl}_{2}$ 5, HEPES 2, and $0.2 \%$ BSA (fatty acid free), $\mathrm{pH}=7.2$. An aliquot of $25 \mu \mathrm{L}$ mitochondrial suspension, containing $4 \mu \mathrm{g}$ of protein, was seated in each well and the plate was centrifuged $\left(2.000 \mathrm{~g} \times 20 \mathrm{~min}\right.$ at $\left.4^{\circ} \mathrm{C}\right)$. The mitochondria were provided with $37^{\circ} \mathrm{C}$ assay buffer containing $10 \mathrm{mM}$ glutamate or $10 \mathrm{mM}$ glutamine both in the presence of $10 \mathrm{mM}$ malate (all final concentrations) and analyzed immediately. Malate was provided to support the pool of TCA cycle intermediates. The sequence of analysis consisted firstly of a waiting period of $10 \mathrm{~min}$, followed by two cycles of mixing $(1 \mathrm{~min})$ and waiting ( $3 \mathrm{~min})$. Subsequently, three cycles of mixing ( $2 \mathrm{~min})$, waiting $(1 \mathrm{~min})$, and measurements $(3 \mathrm{~min})$ were applied to establish the baseline OCR. During the subsequent course of measurements, four compounds were injected, in the following order: ADP $(4 \mathrm{mM})$, oligomycin A $(2.5 \mu \mathrm{g} / \mathrm{mL})$, carbonyl cyanide-p-trifluoromethoxyphenylhydrazone (FCCP, $8 \mu \mathrm{M})$, and antimycin $\mathrm{A}(8 \mu \mathrm{M})$-all final concentrations. OCRs were calculated using the Wave software (Seahorse Biosciences). Relative OCR levels were calculated by setting the OCR at the third baseline measurement to $100 \%$.

2.4. Preparation and Incubation of Acute Brain Slices. Acutely isolated brain slices were prepared as previously described $[19,20]$. Briefly, animals were euthanized by cervical dislocation and the brain excised into ice-cold artificial cerebrospinal fluid (ACSF) containing the following in mM: $\mathrm{NaCl} 128, \mathrm{NaHCO}_{3} 25, \mathrm{KCl} 3, \mathrm{CaCl}_{2} 2, \mathrm{MgSO}_{4}$ 1.2, and $\mathrm{KH}_{2} \mathrm{PO}_{4} 0.4, \mathrm{pH}=7.4$. The cerebral cortices and hippocampi were sliced using a McIlwain Tissue Chopper (The Vibratome Company, O'Fallon, MO, USA) into $350 \mu \mathrm{m}$ thick slices. The slices were incubated in $10 \mathrm{~mL}$ ACSF containing $10 \mathrm{mM} \mathrm{D}$-glucose for $60 \mathrm{~min}$ to recover from the slicing. Subsequently, the media were exchanged for ACSF containing $0.5 \mathrm{mM}\left[\mathrm{U}_{-}{ }^{13} \mathrm{C}\right]$ glutamate or $1 \mathrm{mM}$ $\left[\mathrm{U}_{-}{ }^{13} \mathrm{C}\right.$ ]glutamine both in combination with $5 \mathrm{mM}$ D-glucose, and the slices were incubated for $60 \mathrm{~min}$. The incubations were terminated by transferring slices to icecold $70 \%$ ethanol. Slice were sonicated and centrifuged $(20.000 \mathrm{~g} \times 20 \mathrm{~min})$ and the supernatant was lyophilized and stored for later analysis. The pellets were saved for protein determination by the Pierce method. The dry brain slice extracts were reconstituted in $\mathrm{H}_{2} \mathrm{O}$ for determination of ${ }^{13} \mathrm{C}$ enrichment and amino acid amounts by GC-MS and HPLC analysis, respectively. 
2.5. Metabolic Mapping by Gas Chromatography-Mass Spectrometry (GC-MS) Analysis. GC-MS analysis of ${ }^{13} \mathrm{C}$ enrichment in amino acids and metabolites from brain slice extracts was performed as described by Walls et al. [21]. The natural abundance of ${ }^{13} \mathrm{C}$ was taken into account using data obtained from analysis of standards containing unlabeled metabolites of interest. Data are presented as the \% ${ }^{13} \mathrm{C}$ enrichment of $M+X$, where $M$ is the molecular ion of the given metabolite and $X$ is the number of ${ }^{13} \mathrm{C}$ carbon atoms in the molecule. The expected pattern of ${ }^{13} \mathrm{C}$ labeling from incubations with $\left[\mathrm{U}_{-}{ }^{13} \mathrm{C}\right]$ glutamate and $\left[\mathrm{U}_{-}{ }^{13} \mathrm{C}\right]$ glutamine is given in Figure 1.

2.6. Amino Acid and Lactate Determination. Determination of quantitative amounts of amino acids from brain slice extracts was assessed by reversed-phase high-performance liquid chromatography (HPLC) using precolumn ophthalaldehyde derivatization and fluorescent detection (excitation $\lambda=338 \mathrm{~nm}$, emission $\lambda=390 \mathrm{~nm}$ ) as previously described [19]. The amounts of lactate released from the brain slices to the incubation medium were assessed using an enzymatic kit, based on the coupled reactions between lactate dehydrogenase and alanine aminotransferase, from Boehringer Mannheim/R-Biopharm AG (Darmstadt, Germany) according to the manufacturer's instructions.

2.7. Western Blots. Cerebral cortical and hippocampal homogenates of $\mathrm{db} / \mathrm{db}$ and control mice were analyzed by Western blotting using primary antibodies against GDH, AAT, glutamate decarboxylase (GAD), PAG, and GS. Equal amounts $(30 \mu \mathrm{g})$ of protein were separated by SDS-PAGE using NuPAGE 4-12\% Bis-Tris gels (Thermo Fisher Scientific) before transferring the proteins to PVDF membranes. The membranes were stained with Ponceau $S$ solution for validation of equal protein amounts, washed, and incubated in the given primary antibodies, and appropriate HRPconjugated secondary antibodies (Dako) were used. The blots were subsequently analyzed with $\mathrm{ECL}^{\mathrm{TM}}$ Prime Western Blotting Detection Reagent and quantified using ImageJ software.

2.8. Data Presentation and Statistical Analysis. All data are presented as means \pm standard error of the mean (SEM). To test if differences between the control and $\mathrm{db} / \mathrm{db}$ groups were statistically significant, Student's $t$-test were employed. $P$ values of $<0.05$ were considered to be significant and are indicated with a single asterisk.

\section{Results}

3.1. Mitochondrial Oxidation of Glutamate and Glutamine. To investigate if the cerebral mitochondrial oxidation of glutamate and glutamine was altered in the $\mathrm{db} / \mathrm{db}$ mice, oxygen consumption rates (OCRs) of isolated whole-brain mitochondria were assessed with glutamate and glutamine as substrates, both in the presence of malate. Glutamine is taken up by the mitochondria and transformed into glutamate, which can be converted into $\alpha$-ketoglutarate and support oxidative metabolism in the TCA cycle. Absolute and relative OCRs of isolated whole-brain mitochondria from control and $\mathrm{db} / \mathrm{db}$ mice are presented in Figure 2. Addition of ADP

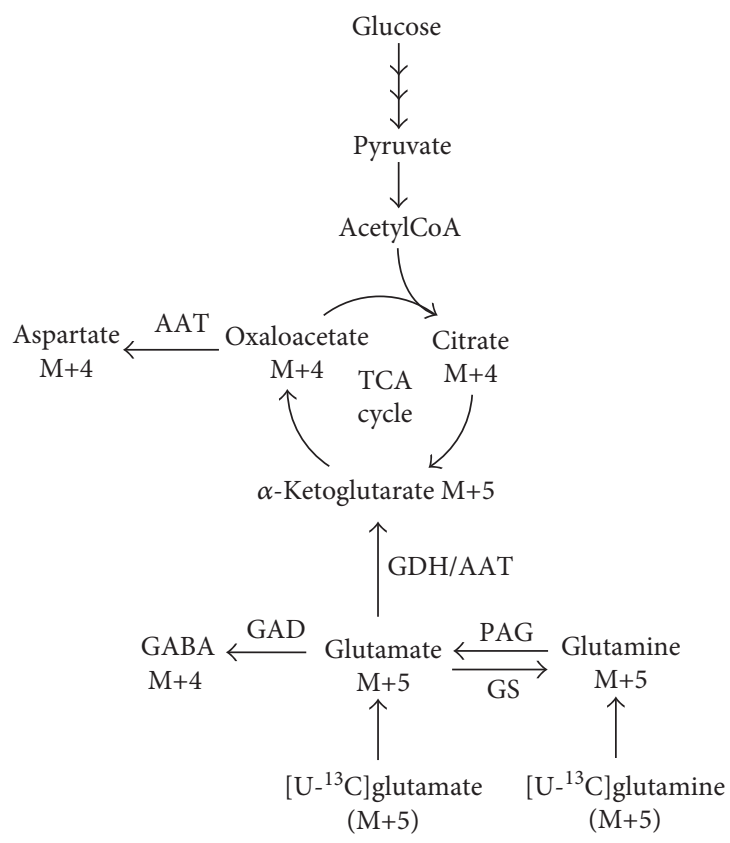

Figure 1: Cartoon illustrating ${ }^{13} \mathrm{C}$ labeling patterns from $\left[\mathrm{U}_{-}{ }^{13} \mathrm{C}\right]$ glutamate and $\left[\mathrm{U}_{-}{ }^{13} \mathrm{C}\right]$ glutamine metabolism. Glutamate $\mathrm{M}+5$ can be converted into glutamine $\mathrm{M}+5$ or GABA $\mathrm{M}+4$ through glutamine synthetase (GS) or glutamate decarboxylase (GAD) activity, respectively. Glutamine $M+5$ can likewise be converted into glutamate $\mathrm{M}+5$ through the action of phosphateactivated glutaminase (PAG). Additionally, glutamate $M+5$ can be converted into $\alpha$-ketoglutarate $\mathrm{M}+5$ by activity of either glutamate dehydrogenase $(\mathrm{GDH})$ or aspartate aminotransferase (AAT) and be introduced into the TCA cycle. $\alpha$-Ketoglutarate $\mathrm{M}+5$ can be metabolized in the TCA cycle, giving rise to ${ }^{13} \mathrm{C}$ labeling in all TCA cycle intermediates. Aspartate is in close equilibrium with oxaloacetate trough AAT, giving rise to aspartate $\mathrm{M}+4$ labeling.

stimulates coupled respiration, which can be blocked by the ATP synthase inhibitor oligomycin A. FCCP induces maximal uncoupled respiration, whereas antimycin A inhibits complex III of the respiratory chain halting the flow of electrons. No significant changes were observed in the OCR of mitochondria from control and $\mathrm{db} / \mathrm{db}$ mice when provided with glutamate (Figure 2(a)) or glutamine (Figure 2(b)) as respiratory substrates in the presence of any of the four compounds. A tendency towards an overall higher OCR was observed in the mitochondria of $\mathrm{db} / \mathrm{db}$ mice for both substrates. However, these tendencies were not present in the relative OCR levels (Figures 2(c) and 2(d)), suggesting little or no changes in cerebral mitochondrial utilization of glutamate and glutamine in the $\mathrm{db} / \mathrm{db}$ mouse.

3.2. Amino Acid Amounts of Isolated Cerebral Cortical and Hippocampal Slices. The content of amino acids of cerebral cortical and hippocampal slices from control and $\mathrm{db} / \mathrm{db}$ mice incubated in media containing $\left[\mathrm{U}-{ }^{13} \mathrm{C}\right]$ glutamate or $\left[\mathrm{U}_{-}{ }^{13} \mathrm{C}\right]$ glutamine is presented in Figure 3. No significant changes were observed in amino acid amounts of cerebral cortical and hippocampal slices incubated in media containing $\left[\mathrm{U}^{13}{ }^{13} \mathrm{C}\right]$ glutamate (Figures $3(\mathrm{a})$ and $3(\mathrm{~b})$ ). A tendency towards lower glutamate levels was observed in the 


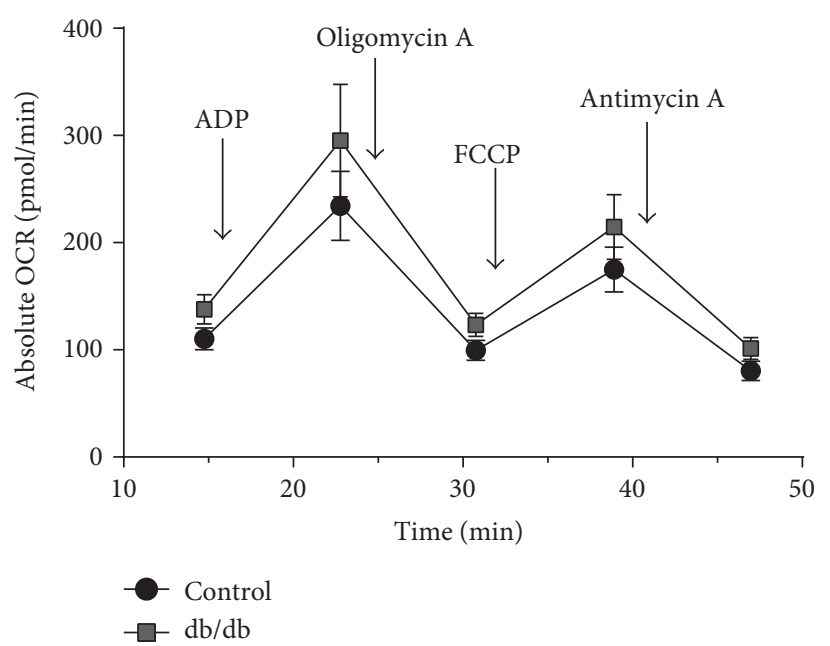

(a)

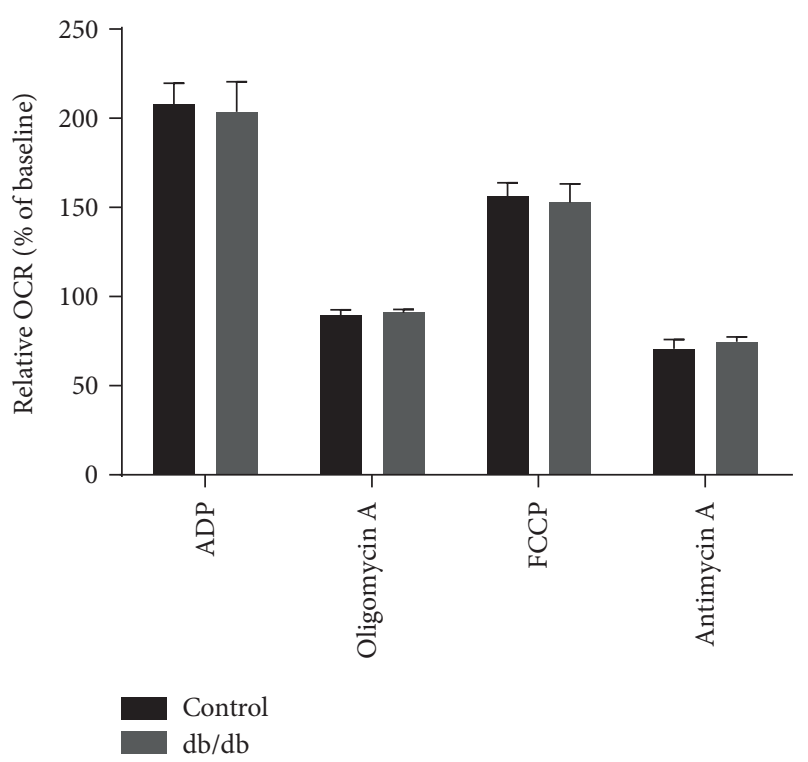

(c)

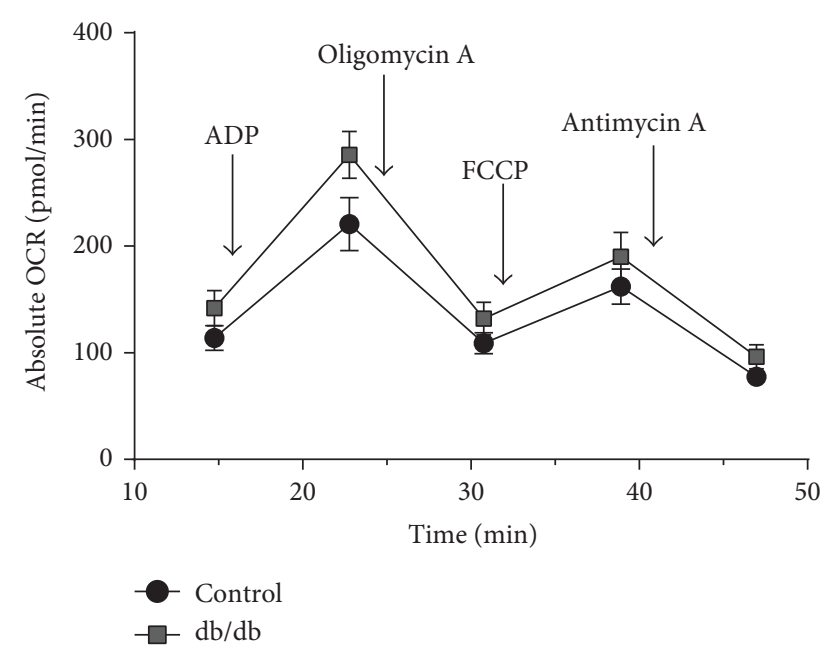

(b)

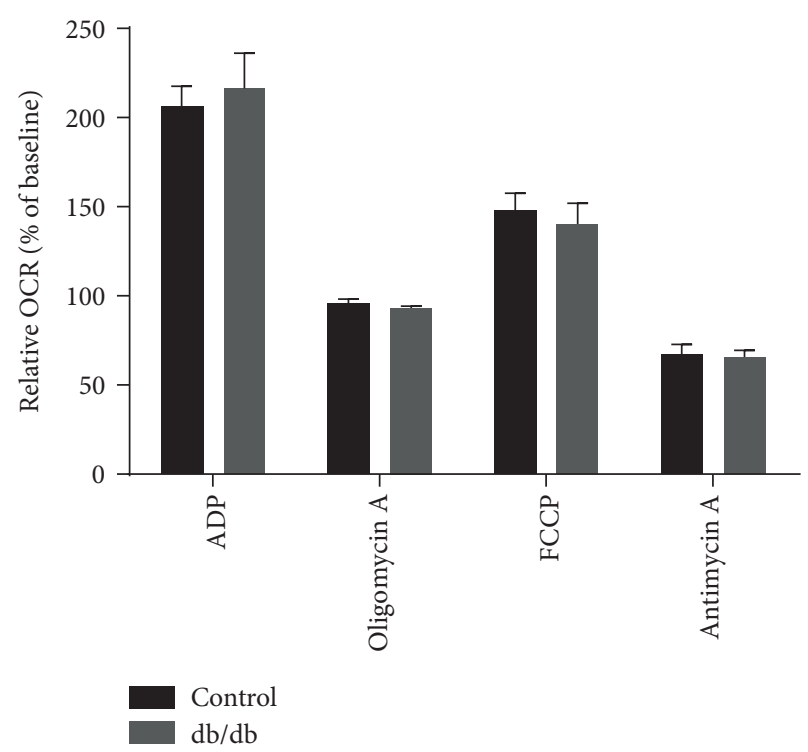

(d)

FIGURE 2: Mitochondrial oxygen consumption rates (OCRs) of isolated brain mitochondria from control and db/db mice. Absolute (a and b) and relative ( $c$ and $d$ ) oxygen consumption rates of the brain mitochondria from control and $\mathrm{db} / \mathrm{db}$ mice, with glutamate (a and $\mathrm{c}$ ) and glutamine ( $b$ and $d$ ), both in the presence of malate, as substrates. Arrows (in a and b) indicate the specific time points of compound addition. ADP stimulates coupled respiration, oligomycin A inhibits the ATP synthase, FCCP induces uncoupled respiration, and antimycin A inhibits complex III of the electron transport chain. Baseline is not shown. Results are presented as means \pm SEM, $n=4-7$, Student's $t$-test, $p<0.05$.

hippocampal slices of $\mathrm{db} / \mathrm{db}$ mice $(p=0.12)$. Likewise, no significant changes in amino acid amounts were observed for cerebral cortical and hippocampal slices of control and $\mathrm{db} / \mathrm{db}$ mice incubated in media containing $\left[\mathrm{U}_{-}{ }^{13} \mathrm{C}\right]$ glutamine (Figures 3(c) and 3(d)). In addition, no significant changes in lactate amounts released to the media during the incubations were observed (data not shown).

3.3. Metabolism of $\left[U_{-}{ }^{13} \mathrm{C}\right]$ Glutamate in Acute Brain Slices. Even though no changes in mitochondrial oxidation of glutamate and glutamine were found in the $\mathrm{db} / \mathrm{db}$ mouse, more subtle regional changes could be present. To detect such changes, acutely isolated cerebral cortical and hippocampal slices were incubated in media containing $\left[\mathrm{U}-{ }^{13} \mathrm{C}\right]$ glutamate or $\left[\mathrm{U}_{-}{ }^{13} \mathrm{C}\right]$ glutamine, and isotopic enrichment was assessed in tissue extracts by GC-MS analysis. The expected labeling pattern of $\left[\mathrm{U}-{ }^{13} \mathrm{C}\right]$ glutamate metabolism is depicted in Figure 1 . The ${ }^{13} \mathrm{C}$ enrichment of amino acids and TCA cycle intermediates from $\left[\mathrm{U}_{-}{ }^{13} \mathrm{C}\right]$ glutamate metabolism in cerebral cortical and hippocampal slices from control and $\mathrm{db} / \mathrm{db}$ mice is presented in Figure 4. No apparent changes were observed in ${ }^{13} \mathrm{C}$ labeling from $\left[\mathrm{U}_{-}{ }^{13} \mathrm{C}\right]$ glutamate metabolism of cerebral cortical slices from control and $\mathrm{db} / \mathrm{db}$ mice (Figure 4(a)). In contrast, ${ }^{13} \mathrm{C}$ enrichment of several metabolites was lower in hippocampal slices of $\mathrm{db} / \mathrm{db}$ mice when compared to controls (Figure 4(b)). Labeling of glutamate 


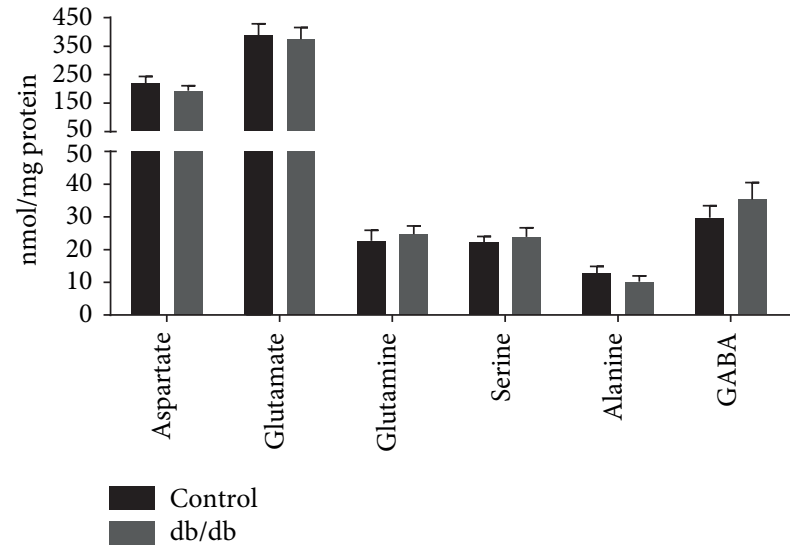

(a)

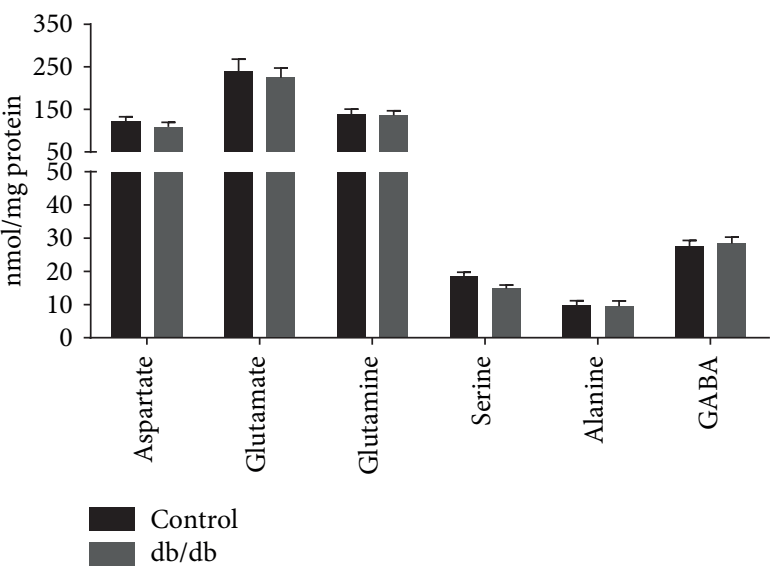

(c)

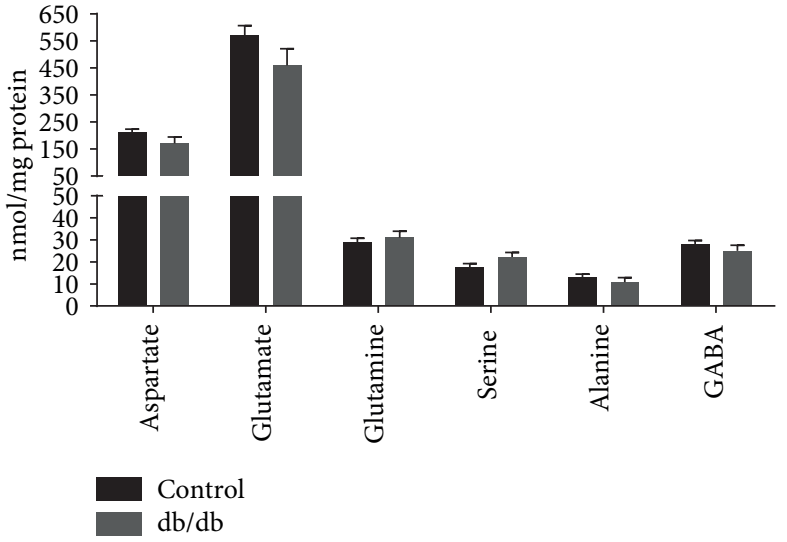

(b)

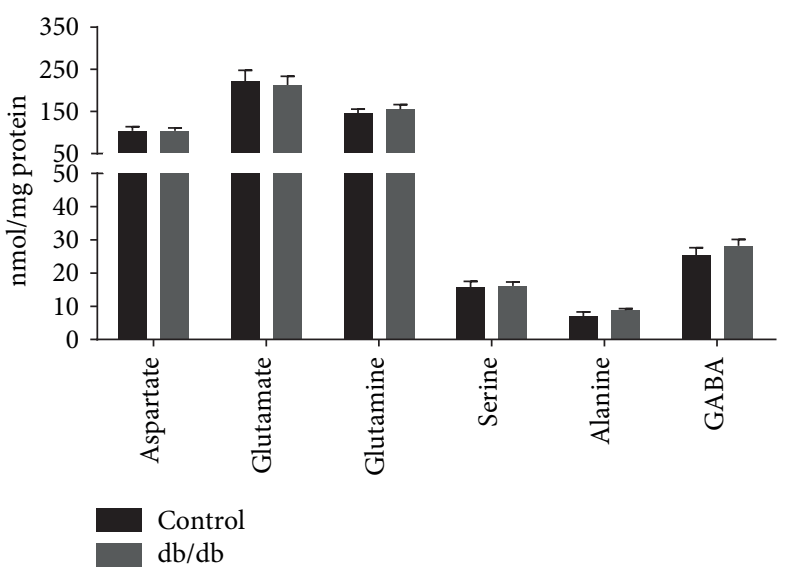

(d)

Figure 3: Amino acid amounts in extracts of cerebral cortical and hippocampal slices of control and db/db mice. Amino acid amounts of cerebral cortical (a and c) and hippocampal (b and $d$ ) slices of control and $\mathrm{db} / \mathrm{db}$ mice incubated in media containing either $\left[\mathrm{U}_{-}{ }^{13} \mathrm{C}\right.$ ]glutamate $\left(\mathrm{a}\right.$ and $\mathrm{b}$ ) or $\left[\mathrm{U}_{-}{ }^{13} \mathrm{C}\right]$ glutamine $(\mathrm{c}$ and $\mathrm{d}$ ). Results are presented as means $\pm \mathrm{SEM}, n=8-11$, Student's $t$-test, $p<0.05$.

$\mathrm{M}+5$ was significantly reduced $(8 \%, p=0.044)$. Additionally, enrichment in glutamine $\mathrm{M}+5$ and GABA $\mathrm{M}+4$ was significantly decreased ( $10 \%, p=0.048$ and $19 \%, p=0.0087$, resp.) in hippocampal slices of $\mathrm{db} / \mathrm{db}$ mice compared to controls. Since glutamate $\mathrm{M}+5$ is the direct precursor of glutamine $\mathrm{M}+5$ and GABA $\mathrm{M}+4$, the reduced labeling of the latter two is likely a reflection of the decreased glutamate $\mathrm{M}+5$ labeling. Furthermore, significant decreases in citrate $\mathrm{M}+4$ $(13 \%, p=0.045)$ and aspartate $M+4(9 \%, p=0.037)$ were observed from $\left[\mathrm{U}_{-}{ }^{13} \mathrm{C}\right]$ glutamate metabolism in the hippocampus of $\mathrm{db} / \mathrm{db}$ mice. These results suggest an impaired metabolism of glutamate, which could be linked to reduced uptake of glutamate in hippocampal slices of $\mathrm{db} / \mathrm{db}$ mice.

3.4. Metabolism of $\left[U_{-}{ }^{13} \mathrm{C}\right]$ Glutamine in Acute Brain Slices. The anticipated labeling pattern from metabolism of $\left[\mathrm{U}_{-}{ }^{13} \mathrm{C}\right]$ glutamine is illustrated in Figure $1 .{ }^{13} \mathrm{C}$ labeling of amino acids and TCA cycle intermediates from $\left[\mathrm{U}_{-}{ }^{13} \mathrm{C}\right] \mathrm{glu}-$ tamine metabolism in cerebral cortical and hippocampal slices from control and $\mathrm{db} / \mathrm{db}$ mice are presented in Figure 5. No significant differences in ${ }^{13} \mathrm{C}$ labeling were observed in extracts of cerebral cortical slices of control and $\mathrm{db} / \mathrm{db}$ mice. However, as seen for the incubations with $\left[\mathrm{U}_{-}{ }^{13} \mathrm{C}\right]$ glutamate, several differences were found in extracts of hippocampal slices of $\mathrm{db} / \mathrm{db}$ mice incubated with $\left[\mathrm{U}_{-}{ }^{13} \mathrm{C}\right]$ glutamine. No significant changes were observed in glutamine $M+5$ or glutamate $M+5$, suggesting unaltered glutamine uptake and PAG activity. However, labeling of GABA $M+4$ was significantly decreased $(10 \%, p=0.045)$ in $\mathrm{db} / \mathrm{db}$ mice compared to controls. Furthermore, labeling of citrate $\mathrm{M}+4$ and aspartate $\mathrm{M}+4$ was significantly reduced $(10 \%, p=0.027$ and $11 \%, p=0.034$, resp.) in hippocampal slices of $\mathrm{db} / \mathrm{db}$ mice. These results point towards hampered metabolism of glutamine, downstream of glutamate, in the hippocampus of $\mathrm{db} / \mathrm{db}$ mice.

3.5. Expression Levels of Enzymes in the Metabolism of Glutamate and Glutamine. The observed changes in ${ }^{13} \mathrm{C}$ labeling from metabolism of $\left[\mathrm{U}_{-}{ }^{13} \mathrm{C}\right]$ glutamate and $\left[\mathrm{U}_{-}{ }^{13} \mathrm{C}\right]$ glutamine could be due to altered expression of enzymes involved in glutamate and glutamine turnover illustrated in Figure 1. However, no changes were observed in the expressions of GDH, AAT, GAD, PAG, or GS in cerebral cortical and hippocampal homogenate of $\mathrm{db} / \mathrm{db}$ and control mice (see 


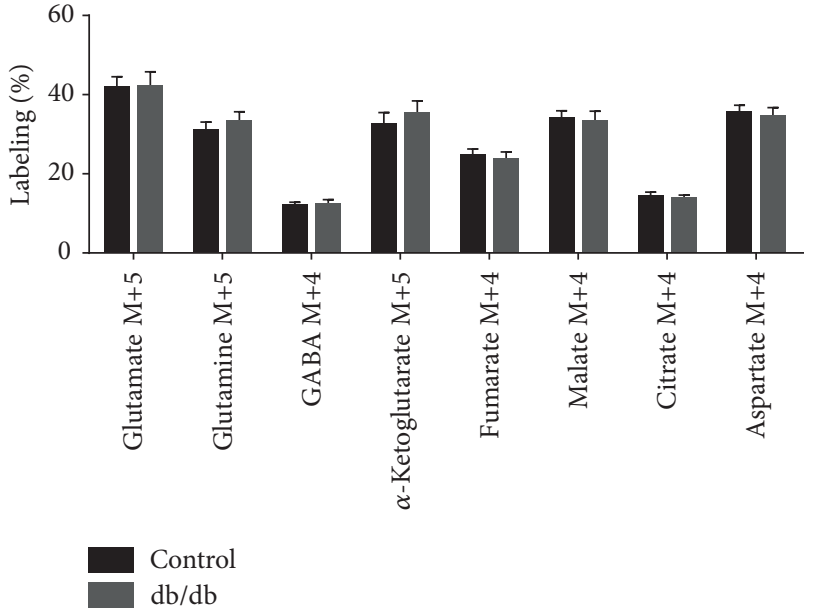

(a)

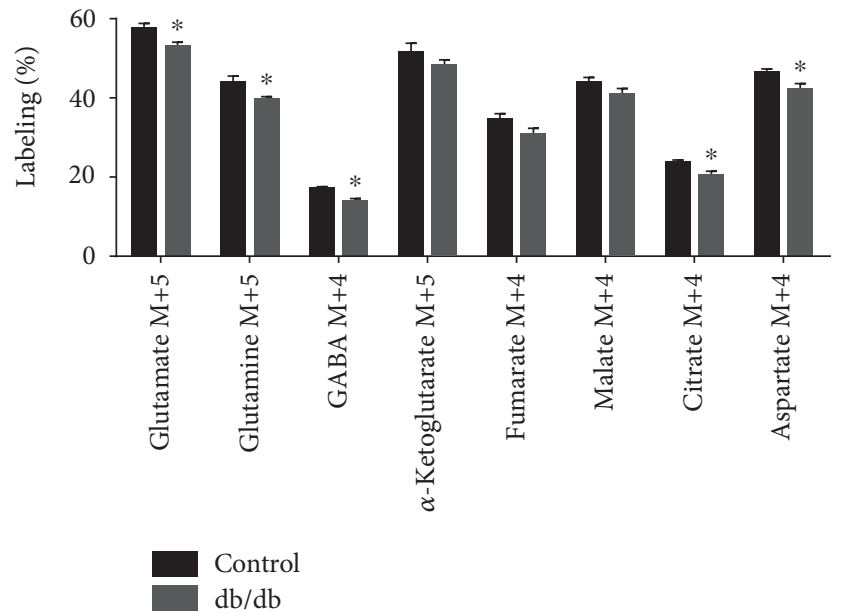

(b)

FIGURE $4:{ }^{13} \mathrm{C}$ labeling from $\left[\mathrm{U}_{-}{ }^{13} \mathrm{C}\right]$ glutamate metabolism of cerebral cortical and hippocampal slices of control and db/db mice. TCA cycle intermediates and amino acids labeled from $\left[\mathrm{U}_{-}{ }^{13} \mathrm{C}\right]$ glutamate metabolism during incubations of cerebral cortical (a) and hippocampal (b) slices of control and $\mathrm{db} / \mathrm{db}$ mice. Results are presented as means \pm SEM, $n=8-11$, Student's $t$-test, ${ }^{*} p<0.05$.

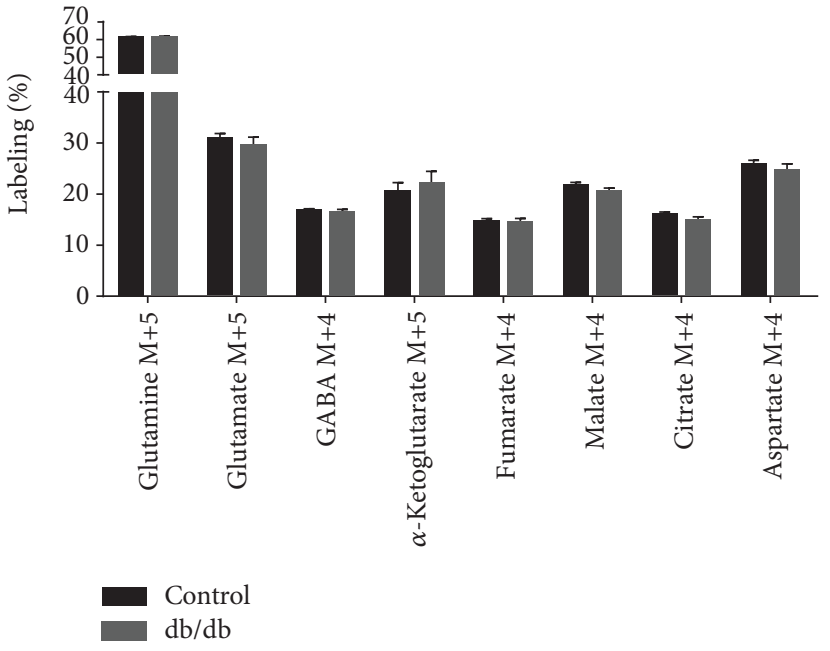

(a)

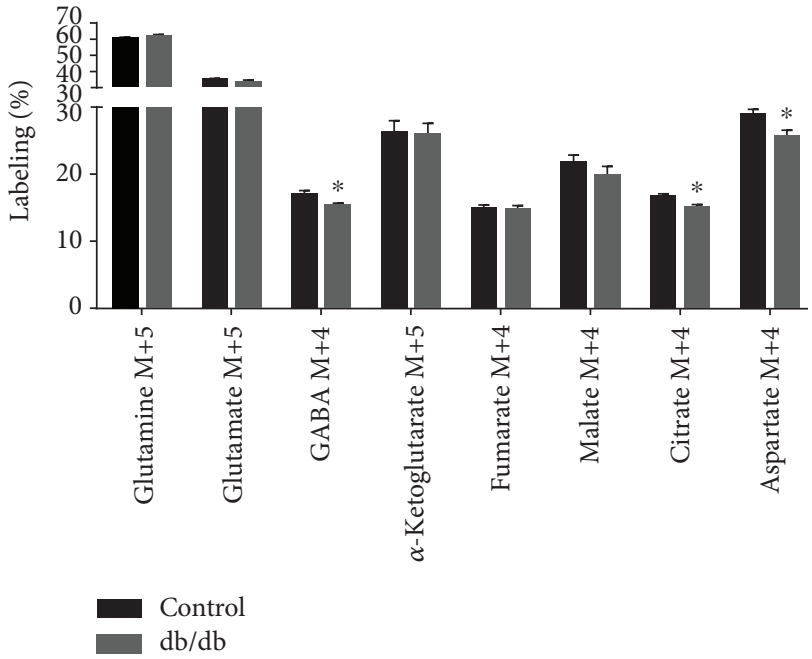

(b)

Figure 5: ${ }^{13} \mathrm{C}$ labeling from $\left[\mathrm{U}^{-13} \mathrm{C}\right]$ glutamine metabolism of cerebral cortical and hippocampal slices of control and db/db mice. TCA cycle intermediates and amino acids labeled from $\left[\mathrm{U}_{-}{ }^{13} \mathrm{C}\right]$ glutamine metabolism during incubations of cerebral cortical (a) and hippocampal (b) slices of control and db/db mice. Results are presented as means \pm SEM, $n=11$, Student's $t$-test, ${ }^{*} p<0.05$.

Supplementary Figure 1 available online at https://doi.org/ $10.1155 / 2017 / 2107084)$.

\section{Discussion}

In this study, we show that the mitochondrial capacity for oxidative metabolism of glutamate and glutamine in the $\mathrm{db} / \mathrm{db}$ brain is maintained. However, hippocampal slices of $\mathrm{db} / \mathrm{db}$ mice exhibited hampered metabolism of glutamate and glutamine, observed as decreased ${ }^{13} \mathrm{C}$ labeling of several key amino acids and TCA cycle intermediates. These results suggest that both glutamate uptake and glutamine metabolism are disturbed in the hippocampus of $\mathrm{db} / \mathrm{db}$ mice, potentially affecting the homeostasis of the glutamate/glutamine cycle.

4.1. Cerebral Mitochondrial Function in Type 2 Diabetes. In the present study, we show no significant changes in oxygen consumption of brain mitochondria from $\mathrm{db} / \mathrm{db}$ mice when provided with glutamate and glutamine, suggesting little or no change in cerebral mitochondrial oxidation of these substrates. Other studies have found impaired cerebral mitochondrial function in the brain of the $\mathrm{db} / \mathrm{db}$ mouse, mainly manifested as decreased expression or activity of the individual electron transport chain complexes in both the cerebral 
cortex and hippocampus [22, 23]. Huang et al. have recently shown an age-related decline of complex I activity in the hippocampus of $\mathrm{db} / \mathrm{db}$ mice [23]. Other studies have, likewise, found reduced hippocampal gene and protein expression related to mitochondrial energetics in $\mathrm{db} / \mathrm{db}$ mice $[24,25]$, all suggesting that the mitochondria of the hippocampus are affected by T2DM. However, oxygen consumption, being a measure of TCA cycle metabolism, electron transport, and oxidative phosphorylation, does not suggest any functional alterations in oxidative metabolism of glutamate and glutamine in the $\mathrm{db} / \mathrm{db}$ brain. We have recently shown, using the same experimental setup, an augmented ADP-stimulated respiration from isolated whole-brain mitochondria of $\mathrm{db} / \mathrm{db}$ mice when given pyruvate and malate as substrates [16]. This could suggest mitochondrial compensatory mechanisms at the level of oxidative phosphorylation in the $\mathrm{db} / \mathrm{db}$ brain. The enhanced mitochondrial function might try to counterbalance the observed cerebral hypometabolism of glucose in $\mathrm{db} / \mathrm{db}$ mice [16]. Our previous observations are in line with the results presented in this study, showing that mitochondrial oxidative function in the $\mathrm{db} / \mathrm{db}$ brain is maintained. However, it should be noted that the mitochondrial preparation used in this study, as done previously, was obtained from whole-brain homogenate, meaning that potential regional differences in mitochondrial function might be masked.

4.2. Glutamate/Glutamine Cycling in the Diabetic Brain. Homeostasis of the glutamate/glutamine cycle is important for normal brain function and has been shown to be altered in T2DM animal models [26, 27]. Impairments of glutamate or glutamine uptake could be reflected as quantitative changes of these amino acids from extracts of the incubated brain slices. We have previously found that the amounts of the amino acids: aspartate, glutamate, glutamine, serine, alanine, and GABA, were unaltered in extracts of both cerebral cortical and hippocampal slices of $\mathrm{db} / \mathrm{db}$ mice incubated in media containing glucose as substrate [16]. This observation is in accordance with previous findings by Makar et al. [28]. However, a recent study found significant increased levels of glutamate and decreased levels of glutamine in the hippocampus of 17 -week-old $\mathrm{db} / \mathrm{db}$ mice assessed by ${ }^{1} \mathrm{H}$-NMR [26]. This study also reported qualitative changes in GS and PAG expression using immunohistochemistry, coinciding with the altered levels of glutamate and glutamine [26]. Our results obtained from acutely isolated brain slices do not support such changes in enzyme expression. From the metabolism of $\left[\mathrm{U}_{-}{ }^{13} \mathrm{C}\right]$ glutamate, the enrichment of glutamate $\mathrm{M}+5$ and glutamine $\mathrm{M}+5$ was decreased to similar extents ( $8 \%$ and $10 \%$, resp.) in hippocampal slices of $\mathrm{db} / \mathrm{db}$ mice, suggesting intact GS activity. Likewise, from the metabolism of $\left[\mathrm{U}^{-13} \mathrm{C}\right]$ glutamine, labeling of glutamate $\mathrm{M}+5$ synthesized by activity of PAG from glutamine $\mathrm{M}+5$ was unaltered like its precursor in hippocampal slices of $\mathrm{db} / \mathrm{db}$ mice. These observations are additionally supported by Western blot analyses, finding no alterations in GS or PAG expression in the cerebral cortex and hippocampus of $\mathrm{db} / \mathrm{db}$ mice.

In the present study, we find that GABA M+4 labeling is decreased from both $\left[\mathrm{U}_{-}{ }^{13} \mathrm{C}\right]$ glutamate and $\left[\mathrm{U}_{-}{ }^{13} \mathrm{C}\right]$ glutamine metabolism in hippocampal slices of $\mathrm{db} / \mathrm{db}$ mice. It has recently been suggested that the $\mathrm{db} / \mathrm{db}$ mouse exhibits a reduced hippocampal expression of GAD [26]. Astrocytederived glutamine is the main precursor for neuronal GABA synthesis, and the significance of this has been established in our current incubation setup [29]. The decreased enrichment in GABA M+4 could be explained by an impaired transfer of astrocytic glutamine to neurons. However, since GABA M+4 enrichment was reduced from the metabolism of both $\left[\mathrm{U}_{-}{ }^{13} \mathrm{C}\right]$ glutamate and $\left[\mathrm{U}_{-}{ }^{13} \mathrm{C}\right]$ glutamine, this points towards specific alterations in GAD functionality. The expressions of both isoforms of GAD (GAD65 and GAD67) were found not to be different in hippocampal homogenate of $\mathrm{db} / \mathrm{db}$ mice. This indicates decreased enzyme activity and not protein expression.

We observed a reduced enrichment of glutamate $\mathrm{M}+5$ and a tendency towards lower glutamate amounts, from incubations of hippocampal slices in media containing $\left[\mathrm{U}_{-}{ }^{13} \mathrm{C}\right]$ glutamate, pointing towards decreased hippocampal glutamate uptake in $\mathrm{db} / \mathrm{db}$ mice. It has been shown that the rate of astrocytic oxidation of glutamate rises with increasing exogenous glutamate concentrations [12]. In the present incubation study, $0.5 \mathrm{mM}$ exogenous $\left[\mathrm{U}_{-}{ }^{13} \mathrm{C}\right]$ glutamate was applied. This concentration is relatively high, testing both glutamate uptake and metabolism for an extended period of time. Glutamate uptake is energetically expensive, as it is coupled to cotransport $\mathrm{Na}^{+}$, requiring high activity of the $\mathrm{Na}^{+} / \mathrm{K}^{+}$-ATPase to maintain ionic homeostasis [8]. Interestingly, it has been shown that $\mathrm{db} / \mathrm{db}$ mice exhibits a reduced activity of the $\mathrm{Na}^{+} / \mathrm{K}^{+}$-ATPase in whole-brain homogenate, which could be linked to a reduced glutamate uptake [28]. Reduced uptake of glutamate has previously been described in the diabetic brain, which is in line with our results suggesting impairments in this important part of the glutamate/glutamine cycle in the hippocampus [30, 31]. Interestingly, it has been suggested that the $\mathrm{Na}^{+} / \mathrm{K}^{+}$-ATPase is mainly fueled by glycolytically derived ATP [32]. This might explain the decreased glutamate uptake, since we previously have shown hypometabolism of glucose in the brain of $\mathrm{db} / \mathrm{db}$ mice [16].

The reduced labeling observed from incubations with $\left[\mathrm{U}_{-}{ }^{13} \mathrm{C}\right]$ glutamine could arise from reduced neuronal TCA cycle activity, as recently shown in a mouse model of early $A D$ [19]. If the TCA cycle activity is decreased, the need for introduction of $\alpha$-ketoglutarate derived from glutamine through glutamate likewise falls, leading to reduced ${ }^{13} \mathrm{C}$ labeling. However, since only reduced labeling is observed in citrate $\mathrm{M}+4$ and no other TCA cycle intermediate, this is not a likely explanation. In addition, our results indicate that glutamine uptake and conversion into glutamate are unaffected. The main enzymes converting glutamate into $\alpha$-ketoglutarate are AAT and GDH as outlined in Figure 1 [7]. One study has reported a decreased expression of AAT in the hippocampus of $\mathrm{db} / \mathrm{db}$ mice [24]. This observation is in line with our results, since aspartate $\mathrm{M}+4$ labeling was reduced from the metabolism of both $\left[\mathrm{U}_{-}{ }^{13} \mathrm{C}\right]$ glutamate and $\left[\mathrm{U}_{-}{ }^{13} \mathrm{C}\right]-$ glutamine, suggesting reduced activity of AAT in the hippocampus of $\mathrm{db} / \mathrm{db}$ mice. The reduced labeling in citrate $\mathrm{M}+4$, likewise observed for both $\left[\mathrm{U}_{-}{ }^{13} \mathrm{C}\right]$ glutamate and $\left[\mathrm{U}_{-}{ }^{13} \mathrm{C}\right.$ ]glutamine metabolism, is also in line with hampered AAT activity. Since aspartate is in fast equilibrium with oxaloacetate, decreased AAT activity would lead to reduced 
labeling of oxaloacetate $\mathrm{M}+4$, which is reflected in citrate $M+4$. We were not able to detect any changes in either AAT or GDH expression in cerebral cortical or hippocampal homogenate of $\mathrm{db} / \mathrm{db}$ mice.

4.3. Hippocampal Impairments in Type 2 Diabetes. We have recently shown that glucose hypometabolism is present in both the cerebral cortex and hippocampus of the $\mathrm{db} / \mathrm{db}$ mouse, being more prominent in the cerebral cortex [16]. In the current study, changes in glutamate and glutamine metabolism were exclusively present in the hippocampus. It has been suggested that the hippocampus is particularly vulnerable to metabolic alterations in T2DM and this has been associated with memory deficits $[4,6]$. Indeed, several studies have determined that the $\mathrm{db} / \mathrm{db}$ mouse exhibits cognitive impairments $[18,33,34]$. In addition, several specific mitochondrial changes have been found in the hippocampus of $\mathrm{db} / \mathrm{db}$ mice [23-25]. Alterations in electrophysiological functions, specifically decreased hippocampal long-term potentiation and depression, important for memory and learning, have been shown in the $\mathrm{db} / \mathrm{db}$ mouse $[23,33,34]$. All of these specific impairments in the hippocampus of the $\mathrm{db} / \mathrm{db}$ mouse are in line with our results of hippocampal changes in the glutamate/glutamine cycle, not being present in the cerebral cortex. Our results are intriguing in the context of the accelerated development of $\mathrm{AD}$ in relation to T2DM, and the specific hippocampal changes in glutamate and glutamine metabolism could be important factors of the underlying pathology.

\section{Conclusions}

We provide evidence that mitochondrial oxidation of glutamate and glutamine in the brain of the $\mathrm{db} / \mathrm{db}$ mouse is unaltered. However, hippocampal slices of $\mathrm{db} / \mathrm{db}$ mice exhibited reduced glutamate uptake and metabolism of glutamine, changes that were not observed in the cerebral cortex. Our findings suggest specific impairments in hippocampal GAD and AAT activities, likely affecting homeostasis of the glutamate/glutamine cycle, which could be linked to cognitive deficits in $\mathrm{db} / \mathrm{db}$ mice.

\section{Abbreviations}

AAT: Aspartate aminotransferase

ACSF: Artificial cerebrospinal fluid

AD: Alzheimer's disease

GAD: Glutamate decarboxylase

GDH: Glutamate dehydrogenase

GS: $\quad$ Glutamine synthetase

M: $\quad$ Molecular ion

OCR: Oxygen consumption rate

PAG: Phosphate-activated glutaminase

T2DM: Type 2 diabetes mellitus.

\section{Conflicts of Interest}

The authors have nothing to declare.

\section{Authors' Contributions}

Jens Velde Andersen, Jakob Dahl Nissen, and Helle Sønderby Waagepetersen designed the experiments. Jens Velde Andersen, Jakob Dahl Nissen, Sofie Kjellerup Christensen, and Kia Hjulmand Markussen performed the experiments and analyzed the data. Jens Velde Andersen and Helle Sønderby Waagepetersen wrote the manuscript. All authors have approved and provided critical input to the final manuscript.

\section{Acknowledgments}

This project is financially supported by the Novo Nordisk Foundation (NNF-12359, Helle Sønderby Waagepetersen), the Lundbeck Foundation (Jens Velde Andersen), the Memorial Foundation of Eva and Hans Carl Adolf Holm (Jens Velde Andersen), and the Scholarship of Peter and Emma Thomsen (Jens Velde Andersen).

\section{References}

[1] World Health Organization, Global Report on Diabetes, WHO Press, Geneva, Switzerland, 2016.

[2] K. Gudala, D. Bansal, F. Schifano, and A. Bhansali, "Diabetes mellitus and risk of dementia: a meta-analysis of prospective observational studies," Journal of Diabetes Investigation, vol. 4, no. 6, pp. 640-650, 2013.

[3] P. K. Crane, R. Walker, R. A. Hubbard et al., "Glucose levels and risk of dementia," The New England Journal of Medicine, vol. 369, no. 6, pp. 540-548, 2013.

[4] S. M. Gold, I. Dziobek, V. Sweat et al., "Hippocampal damage and memory impairments as possible early brain complications of type 2 diabetes," Diabetologia, vol. 50, no. 4, pp. 711-719, 2007.

[5] L. D. Baker, D. J. Cross, S. Minoshima, D. Belongia, G. S. Watson, and S. Craft, "Insulin resistance and Alzheimer-like reductions in regional cerebral glucose metabolism for cognitively normal adults with prediabetes or early type 2 diabetes," Archives of Neurology, vol. 68, no. 1, pp. 51-57, 2011.

[6] G. J. Biessels and L. P. Reagan, "Hippocampal insulin resistance and cognitive dysfunction," Nature Reviews. Neuroscience, vol. 16, no. 11, pp. 660-671, 2015.

[7] M. C. McKenna, "The glutamate-glutamine cycle is not stoichiometric: fates of glutamate in brain," Journal of Neuroscience Research, vol. 85, no. 15, pp. 3347-3358, 2007.

[8] L. K. Bak, A. Schousboe, and H. S. Waagepetersen, "The glutamate/GABA-glutamine cycle: aspects of transport, neurotransmitter homeostasis and ammonia transfer," Journal of Neurochemistry, vol. 98, no. 3, pp. 641-653, 2006.

[9] M. C. McKenna, "Glutamate pays its own way in astrocytes" Frontiers in Endocrinology, vol. 4, p. 191, 2013.

[10] U. Sonnewald, "Glutamate synthesis has to be matched by its degradation-where do all the carbons go?" Journal of Neurochemistry, vol. 131, no. 4, pp. 399-406, 2014.

[11] M. C. McKenna, M. H. Stridh, L. F. McNair, U. Sonnewald, H. S. Waagepetersen, and A. Schousboe, "Glutamate oxidation in astrocytes: roles of glutamate dehydrogenase and aminotransferases," Journal of Neuroscience Research, vol. 94, no. 12, pp. 1561-1571, 2016. 
[12] M. C. McKenna, U. Sonnewald, X. Huang, J. Stevenson, and H. R. Zielke, "Exogenous glutamate concentration regulates the metabolic fate of glutamate in astrocytes," Journal of Neurochemistry, vol. 66, no. 1, pp. 386-393, 1996.

[13] E. Olstad, H. Qu, and U. Sonnewald, "Glutamate is preferred over glutamine for intermediary metabolism in cultured cerebellar neurons," Journal of Cerebral Blood Flow and Metabolism, vol. 27, no. 4, pp. 811-820, 2007.

[14] U. Sonnewald, N. Westergaard, P. Jones, A. Taylor, H. S. Bachelard, and A. Schousboe, "Metabolism of [U-13C5] glutamine in cultured astrocytes studied by NMR spectroscopy: first evidence of astrocytic pyruvate recycling," Journal of Neurochemistry, vol. 67, no. 6, pp. 2566-2572, 1996.

[15] J. D. Nissen, K. Pajecka, M. H. Stridh, D. M. Skytt, and H. S. Waagepetersen, "Dysfunctional TCA-cycle metabolism in glutamate dehydrogenase deficient astrocytes," Glia, vol. 63, no. 12, pp. 2313-2326, 2015.

[16] J. V. Andersen, S. K. Christensen, J. D. Nissen, and H. S. Waagepetersen, "Improved cerebral energetics and ketone body metabolism in db/db mice," Journal of Cerebral Blood Flow and Metabolism, vol. 37, no. 3, pp. 1137-1147, 2017.

[17] K. P. Hummel, M. M. Dickie, and D. L. Coleman, "Diabetes, a new mutation in the mouse," Science, vol. 153, no. 3740, pp. 1127-1128, 1966.

[18] J. J. Ramos-Rodriguez, O. Ortiz, M. Jimenez-Palomares et al., "Differential central pathology and cognitive impairment in pre-diabetic and diabetic mice," Psychoneuroendocrinology, vol. 38, no. 11, pp. 2462-2475, 2013.

[19] J. V. Andersen, S. K. Christensen, B. I. Aldana, J. D. Nissen, H. Tanila, and H. S. Waagepetersen, "Alterations in cerebral cortical glucose and glutamine metabolism precedes amyloid plaques in the APPswe/PSEN1dE9 mouse model of Alzheimer's disease," Neurochemical Research, vol. 42, no. 6, pp. 1589-1598, 2017.

[20] L. F. McNair, R. Kornfelt, A. B. Walls et al., "Metabolic characterization of acutely isolated hippocampal and cerebral cortical slices using $\left[\mathrm{U}-{ }^{13} \mathrm{C}\right]$ glucose and $\left[1,2-{ }^{13} \mathrm{C}\right]$ acetate as substrates," Neurochemical Research, vol. 42, no. 3, pp. 810826, 2017.

[21] A. B. Walls, L. K. Bak, U. Sonnewald, A. Schousboe, and H. S. Waagepetersen, "Metabolic mapping of astrocytes and neurons in culture using stable isotopes and gas chromatography-mass spectrometry (GC-MS)," in Brain Energy Metabolism, J. Hirrlinger and H. S. Waagepetersen, Eds., vol. 90, Humana Press, New York, 2014.

[22] Y. Peng, J. Liu, L. Shi et al., "Mitochondrial dysfunction precedes depression of AMPK/AKT signaling in insulin resistance induced by high glucose in primary cortical neurons," Journal of Neurochemistry, vol. 137, no. 5, pp. 701-713, 2016.

[23] S. Huang, Y. Wang, X. Gan et al., "Drp1-mediated mitochondrial abnormalities link to synaptic injury in diabetes model," Diabetes, vol. 64, no. 5, pp. 1728-1742, 2015.

[24] A. Ernst, A. N. Sharma, K. M. Elased, P. C. Guest, H. Rahmoune, and S. Bahn, "Diabetic $\mathrm{db} / \mathrm{db}$ mice exhibit central nervous system and peripheral molecular alterations as seen in neurological disorders," Translational Psychiatry, vol. 3, article ID e263, 2013.

[25] C. Sims-Robinson, S. Zhao, J. Hur, and E. L. Feldman, "Central nervous system endoplasmic reticulum stress in a murine model of type 2 diabetes," Diabetologia, vol. 55, no. 8 , pp. 2276-2284, 2012.
[26] Y. Zheng, Y. Yang, B. Dong et al., "Metabonomic profiles delineate potential role of glutamate-glutamine cycle in $\mathrm{db} / \mathrm{db}$ mice with diabetes-associated cognitive decline," Molecular Brain, vol. 9, p. 40, 2016.

[27] H. M. Sickmann, H. S. Waagepetersen, A. Schousboe, A. J. Benie, and S. D. Bouman, "Obesity and type 2 diabetes in rats are associated with altered brain glycogen and amino-acid homeostasis," Journal of Cerebral Blood Flow and Metabolism, vol. 30, no. 8, pp. 1527-1537, 2010.

[28] T. K. Makar, B. L. Hungund, G. A. Cook, K. Kashfi, and A. J. Cooper, "Lipid metabolism and membrane composition are altered in the brains of type II diabetic mice," Journal of Neurochemistry, vol. 64, no. 5, pp. 2159-2168, 1995.

[29] J. V. Andersen, L. F. McNair, A. Schousboe, and H. S. Waagepetersen, "Specificity of exogenous acetate and glutamate as astrocyte substrates examined in acute brain slices of female mice using methionine sulfoximine (MSO) to inhibit glutamine synthesis," Journal of Neuroscience Research, 2017.

[30] E. Galanopoulos, V. Lellos, M. Papadakis, H. Philippidis, and G. Palaiologos, "Effects of fasting and diabetes on some enzymes and transport of glutamate in cortex slices or synaptosomes from rat brain," Neurochemical Research, vol. 13, no. 3, pp. 243-248, 1988.

[31] A. Duarte, M. Santos, R. Seica, and C. Resende de Oliveira, "Effect of oxidative stress on the uptake of GABA and glutamate in synaptosomes isolated from diabetic rat brain," Neuroendocrinology, vol. 72, no. 3, pp. 179-186, 2000.

[32] A. Schousboe, H. M. Sickmann, A. B. Walls, L. K. Bak, and H. S. Waagepetersen, "Functional importance of the astrocytic glycogen-shunt and glycolysis for maintenance of an intact intra/extracellular glutamate gradient," Neurotoxicity Research, vol. 18, no. 1, pp. 94-99, 2010.

[33] A. M. Stranahan, T. V. Arumugam, R. G. Cutler, K. Lee, J. M. Egan, and M. P. Mattson, "Diabetes impairs hippocampal function through glucocorticoid-mediated effects on new and mature neurons," Nature Neuroscience, vol. 11, no. 3, pp. 309-317, 2008.

[34] X. L. Li, S. Aou, Y. Oomura, N. Hori, K. Fukunaga, and T. Hori, "Impairment of long-term potentiation and spatial memory in leptin receptor-deficient rodents," Neuroscience, vol. 113, no. 3, pp. 607-615, 2002. 

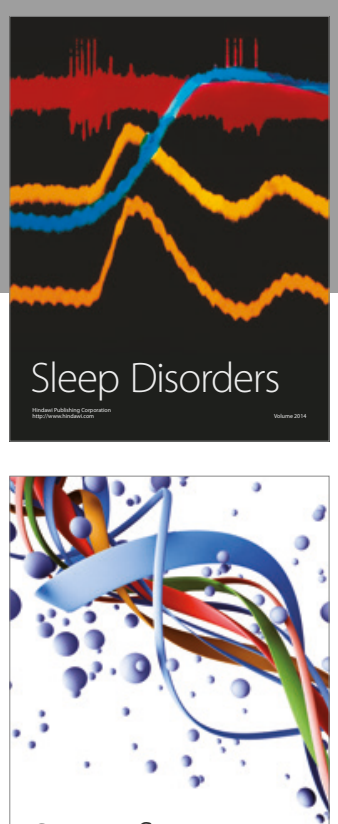

Scientifica
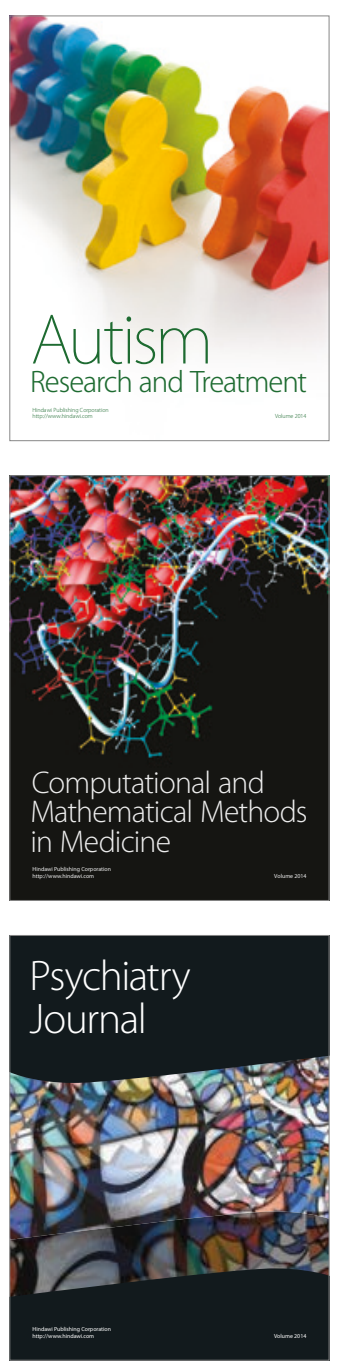
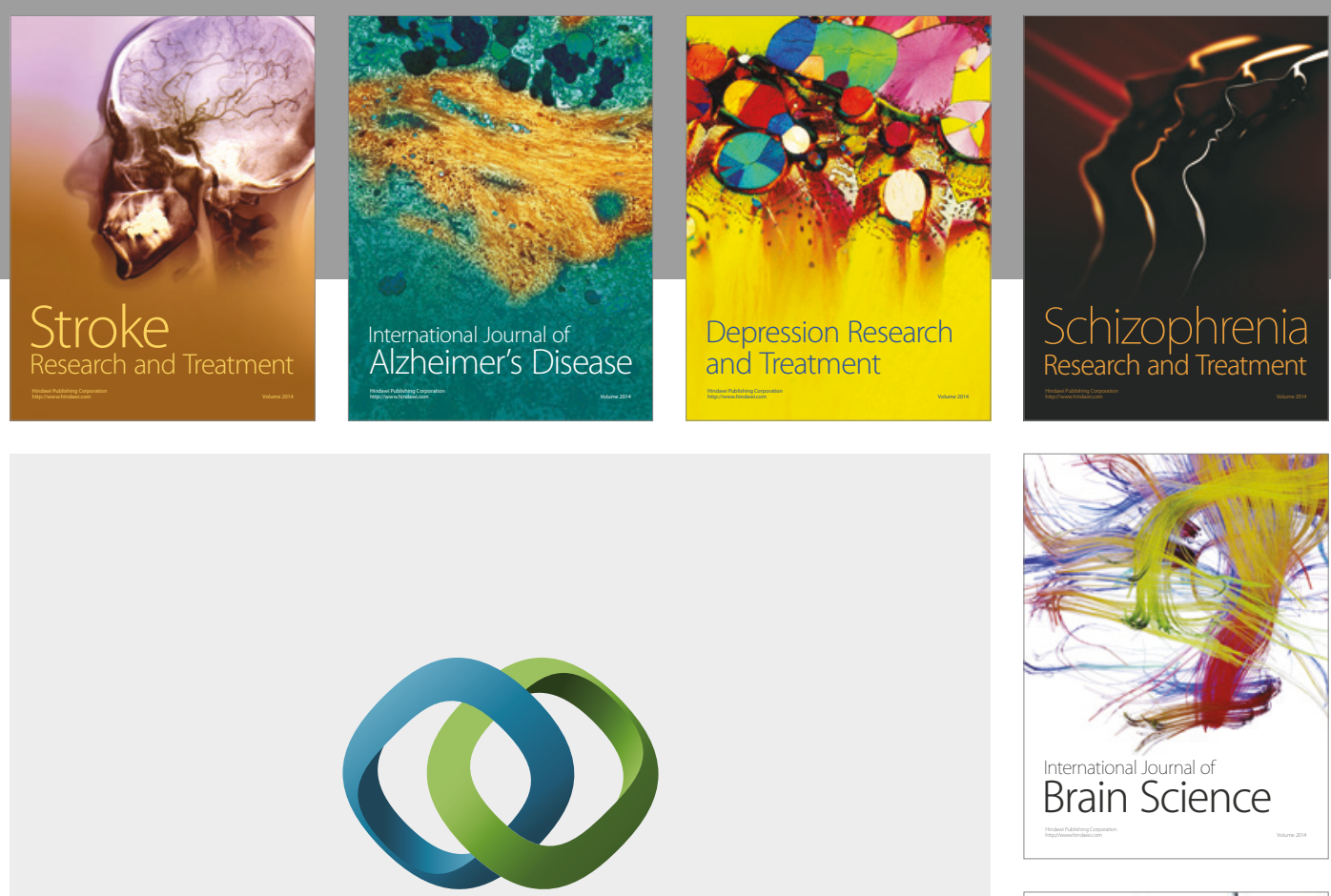

\section{Hindawi}

Submit your manuscripts at

https://www.hindawi.com
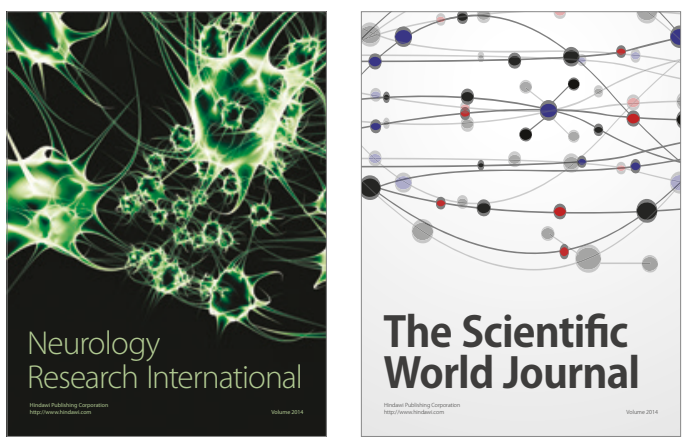

The Scientific World Journal

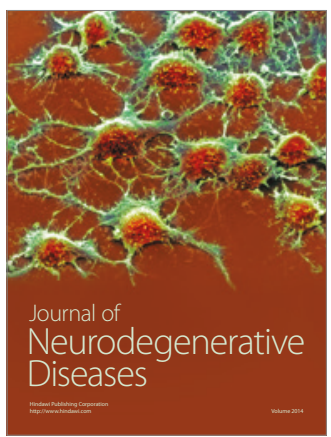

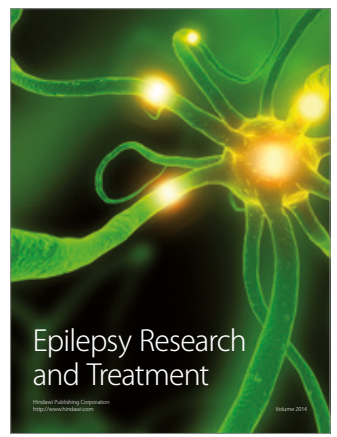

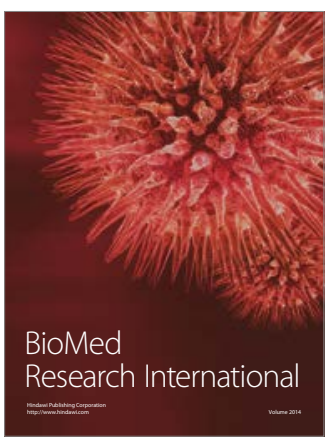

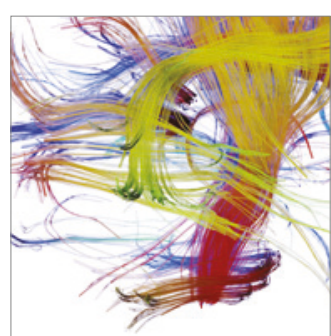

Brain Science

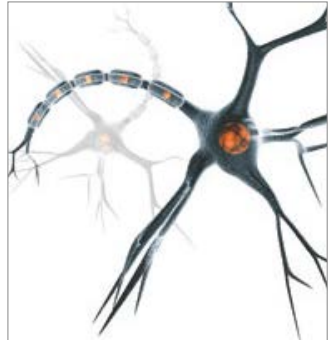

Neural Plasticity
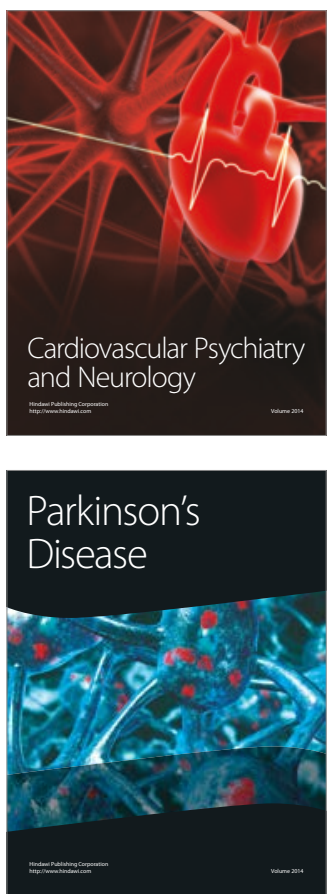